Running Head: REDUCING CRIME RISK TROUGH COMMUNICTION

\title{
Reducing the Risk of Being a Victim of Crime in South Africa: You can Tell and be Heard!
}

\author{
Juan Bornman $^{\mathrm{a}}$, Diane Nelson Bryen ${ }^{\mathrm{b}}$, Priscilla Kershaw ${ }^{\mathrm{a}}$ and Gloria Ledwaba ${ }^{\mathrm{a}}$ \\ ${ }^{\mathrm{a} C e n t r e}$ for Augmentative and Alternative Communication, University of Pretoria, South Africa \\ ${ }^{\mathrm{b}}$ Temple University
}

Correspondence

Juan Bornman

Address: $\quad$ Centre for Augmentative and Alternative Communication,

University of Pretoria

0002 PRETORIA

South Africa

Telephone: $\quad * * 27124202001$

Fax: $\quad$ **27 124204389

Email: Juan.Bornman@up.ac.za 
Reducing crime risk through communication

\begin{abstract}
People who use AAC know that silence is not always golden. Persons with disability, and in particular those with complex communication needs, have a heightened risk of becoming the victim of crime, abuse and neglect. In order to address one of the several problems associated with this, the present study looked at vocabulary needed to disclose or report crime or abuse in South Africa. Furthermore, it also focussed on the development of communication boards in four of the 11 official South African languages (Afrikaans, English, Sepedi and isiZulu). Thirty-six participants were involved in 4 language-based focus groups (English, Afrikaans, Sepedi and isiZulu). Participants were asked to generate a list of possible words they deemed important when wanting to disclose a crime, abuse or neglect. Participants then prioritized the top 55 words. When the lists from the four language groups were compared, a total of 56 words appeared on two or more of the lists. An electronic mail survey indicated that Picture Communication Symbols (PCS $\left.{ }^{\mathrm{TM}}\right)$ were the most frequently used symbol set in South Africa, and hence the board was developed using PCS ${ }^{\mathrm{TM}}$. A discrepancy analysis revealed that these 56 words could be represented by a staggering 219 symbols, of which 2 words (swear, threaten) did not have any existing PCSTM symbols. Consequently, they were developed. It is hoped that the process of developing the communication boards described in this paper might also be useful to the AAC community in other countries. Futhmore, the communicaton boards developed in this study can serve as a template for other languages.
\end{abstract}

\title{
Keywords
}

crime; discrepancy analysis; multi-lingual issues; risk factors; vocabulary development; vulnerable groups; AAC 
Reducing crime risk through communication

Crime against people with developmental and other disabilities is similar in scope to that of women, children and the elderly. However, their victimization continues to remain largely invisible and unaddressed (Bryen, Carey, \& Frantz, 2005; Sobsey, 1994). Research from the United States indicates that people with developmental disabilities are four to ten times more likely to be victims of a crime and that crimes against them are less likely to be reported or prosecuted (Martin, Ray, Sotres-Alvares, Kupper, Moracco \& Dickens, 2006).

People with disabilities are particularly vulnerable to crimes of a sexual nature and they are often repeat victims (Nosek, Howland \& Young, 1997; Sobsey \& Doe, 1991). Keilty and Connelly's (2001) research noted that over 50\% of women with disability had experienced sexual exploitation (assault, rape or abuse) by the time they reach adulthood. According to UNICEF (2005), instances of sexual abuse involving teenagers with intellectual disability in developing countries tend to be 1.7 times greater than those committed against their non-disabled peers. Brownridge (2006) noted that on average more than $50 \%$ of women with disability in developed countries had experienced sexual exploitation by the time they reached adulthood. Women with disability in these countries also reported significantly longer durations of physical and sexual abuse when compared to women without disabilities (Nosek et al., 2001).

Children with disabilities are more than twice as likely as children without disabilities to be physically and sexually abused (Sullivan, 2000). Girls with disability are particularly vulnerable, with high rates of violence resulting in health risks, trauma, adolescent pregnancy and susceptibility to HIV/AIDS (Rousso, 2003).

Virtually no statistics are available on the prevalence of crimes against people with disabilities in South Africa, although figures are obtainable for crimes committed against other vulnerable groups, such as women and children. Taking general South African crime statistics as well as global trends into consideration, however, the high risk that people with 
Reducing crime risk through communication

disability in South Africa face becomes apparent. South Africa is currently listed as the country with the highest incidence of rape per capita and the second highest incidence of murder, while it takes $10^{\text {th }}$ place in ranking when total crime statistics are considered (Nation Builder, 2009, statistics based on The Eighth United Nations Survey on Crime Trends and the Operations of Criminal Justice Systems (2001 - 2002) and the United Nations Office on Drugs and Crime (2005)). There thus seems to be a particularly higher incidence of serious crimes (such as murder and rape) in South Africa than anywhere else in the world. At the same time, crimes committed in South Africa are not necessarily reported to the police - this is especially so when it comes to crimes committed against vulnerable groups, such as women and children. In 1996, for example, Child Welfare Societies dealt with 9,398 cases a month involving severe neglect or physical/sexual abuse (United Nations, 1999), which would have amounted to an estimate of over 112,000 cases over that year (newer statistics were not available). In the same year, the Child Protection Unit (which is the only source of the latest official statistics on crimes against children) of the South African Police Service dealt with only 35,838 cases of crimes against children (Pierce \& Bozalek, 2004). It is thus clear that official crime statistics are under representing the magnitude of the problem of abuse against children, including children with disabilities. According to Judge Keith Matthee in the Grahamstown High Court in South Africa, only $36 \%$ of all reported rape cases in the Eastern Cape Province ever reached the court, and only 5.9\% resulted in convictions (Cohen \& George, 2007).

The high incidence of abuse of people with disability seems directly related to the perpetrators' recognition of their vulnerability. Perpetrators are often well-known to their victims and believe that their victims are unable to seek help or report the crime, while the victims fear backlash from the perpetrator, particularly in cases where the perpetrator also provides personal assistance (Powers \& Oschwald, 2004; Coetzee, 2005; Madu, 2001; Rand 
Reducing crime risk through communication

\& Harrell, 2009).

Misconceptions about the sexuality of people with disability (and especially those with cognitive impairment) could also predispose this population to be more vulnerable to sexual abuse. The sexuality of this group is often misunderstood. At the one end of the spectrum, there is the belief that they are sexually innocent - children forever. Inherent to this myth is the perception that they have little or no understanding of their bodies making them prime targets for those individuals who seek sexual gratification from the abusive act.

The other side of the spectrum reflects the belief that individuals with disability are over-sexed and uncontrolled. This misconception might be the result of them being overly friendly with familiar people and strangers alike and displaying inappropriate sexual expressions or behaviours that make others feel uncomfortable, such as public masturbation. The real reasons might be the lack of information that individuals with developmental disabilities have about which behaviours are acceptable and which are not, and their difficulty in making sense out of images portrayed in the media like music videos, television and magazines.

Certain beliefs regarding sexuality and sexual practices which affect persons with disability have been reported by South African authors. Virgin cleansing, for example, refers to the belief that sex with a virgin is a cure for HIV/AIDS (Grobbelaar-du Plessis, 2007; Groce \& Trasi, 2004; Phasha \& Myaka, 2009). This has lead to sexual abuse and rape of many girls and women with disability by men with HIV/AIDS who see these girls and women as "the fresh ones" (Hanass-Hancock, 2009). In a recent study conducted in the Eastern Cape and Kwa-Zulu Natal provinces in South Africa, one in four men (27.6\%) admitted to having forced a woman or girl to have sex against her will (Jewkes, Sikweyiya, Morrell \& Dunkle, 2008). Given the HIV/AIDS pandemic in South Africa, rape and sexual assault is often a death sentence due to the risk of contracting the HIV virus that causes AIDS (Coetzee, 2005). 
Reducing crime risk through communication

There is also anecdotal evidence that some poor families are selling their disabled daughters into prostitution. Prostitution rings regard these girls as "good catches" since disability-related limitations is thought to make their escape impossible (Rousso, 2003).

In some South African communities, sex with girls and women with intellectual disability is done in the name of Ukuthwala (Phasha \& Myaka, 2009). Perpetrators believe that they will become powerful, feared by others and wealthy if they have sexual intercourse with a "mermaid" (described as a wealth-giving creature) - a spirit who is believed to live within persons with intellectual disability. Sometimes, sexual abuse of these women is interpreted as a blessing, in that the woman with the disability should "count herself lucky" to have sexual intercourse (Hanass-Hancock, 2009).

Furthermore, the reason why crimes against those with disabilities often remain invisible and unaddressed is because crimes are often covered up by communities or disability service providers (Brownridge, 2006). This creates a troublesome paradox: while there are higher rates of crimes against people with disabilities, there are simultaneous lower rates of disclosure and reporting the crime to the police (Davies, 2002). While disclosure is difficult for everyone, women report greater difficulty in naming the abuse (Powers \& Oschwald, 2004). When crime and abuse are reported, they are often handled administratively rather than through criminal prosecution. This might be due to the fact that the police, lawyers, judges and even rape-crisis counsellors, who all form part of the legal protection system, often have no knowledge of how to help a person with disability and therefore find the whole process too daunting (Groce \& Trasi, 2004). Sadly, it also appears that sexual abuse incidents of individuals with disabilities are viewed as less serious than of persons without disability. Consequently, lighter court sentences seem to be issued in cases where the victims have been people with disability (Williams, 1993).

Individuals with disabilities who have complex communication needs face a double 
Reducing crime risk through communication

vulnerability when it comes to crime, abuse, and neglect as they are often the voiceless and invisible members of society (Bryen \& Frantz, 2004; Bryen, Carey, \& Frantz, 2005; Davis, 2002). There are many reasons for this increased vulnerability. Firstly, there is the very real risk that they are unable to make themselves heard and call for help (Hanass-Hancock, 2009). Secondly there is the misconception that these individuals are undeveloped, that they lack basic understanding (poor receptive language abilities), are unable to make choices and that they cannot communicate their intent, which seems attractive to potential perpetrators. Thirdly, they are seen as being unable to tell about their victimization due to their communication difficulty (Howe, 2000). Fourthly, when they do tell they are less likely to be believed because they may not be understood due to their communication disability. In some instances this has lead to caregivers believing that the process of telling and subsequent investigation will do more harm than good for the person with the disability (HanassHancock, 2009). Finally, there is the perception that they are unable to testify in court on their own behalf due to competency issues and other criminal codes about hearsay, confrontation, and leading the witness (Borthwick \& Crossley, 1998; Bryen, 2009). This may be due to the fact that the vocabulary and symbols needed to report their victimization and to testify in court may not be available to them either on communication boards or stored in programmable speech generating devices.

Developing communication access for people with developmental disabilities who don't communicate in traditional ways (sign language or communication boards) is an important factor that needs addressing. In her study of vocabulary for socially-valued adult roles, Bryen (2008) compiled word lists appropriate for a variety of adult roles based on input from persons using AAC and professionals. These word lists were then used to conduct discrepancy analyses to determine whether the words identified could be represented by existing symbols/symbol combinations from each of three major symbol sets used in the 
Reducing crime risk through communication

United States. Bryen found that only $39-78 \%$ of words needed to communicate about sex and sexuality could be represented, and only $39-81 \%$ of words needed to talk about crime and abuse. While this may not be a problem for individuals who rely on AAC and who can spell, it certainly is a problem for those who rely on other symbols or words pre-programmed by others. In South Africa, where low literacy levels amongst people with disabilities are exacerbated due to lack of appropriate schooling (Integrated National Disability Strategy [INDS], 1997) and where incidences of both disability and crime are high, development of picture-based communication tools that enable people with limited or no functional speech to report on crime and/or abuse seems an urgent necessity. However, no studies have yet addressed the development of such tools.

\section{Method}

In order to address one of the several problems associated with the high rates of crime, abuse, and neglect against individuals with complex communication needs $(\mathrm{CCN})$, this study looked at vocabulary needed to disclose or report crime or abuse in South Africa. In addition, the research lead to the development of communication boards in four of the 11 official South African languages (Afrikaans, English, Sepedi and isiZulu) so that both children and adults with $\mathrm{CCN}$ who are non-literate could tell a first responder that they have been a victim of crime, abuse, or neglect. A first responder describes a professional person to whom the situation is disclosed in an attempt to obtain help. Such a person could include a religious leader, a paramedic, teacher, therapist, police or security officer, or a social worker. The primary aim of the communication boards is thus to enable the first time reporting/disclosure of a crime, rather than testifying about a crime in a court of law. The specific four languages were selected as they are frequently spoken languages in the South Africa (Lehohla, 2003).

The first step entailed selecting appropriate vocabulary for the boards. The second step 
Reducing crime risk through communication

entailed representing this vocabulary by means of appropriate symbols to enable people with $\mathrm{CCN}$ who are non-literate to tell about what happened to them.

The aim of the first step was to generate a list of approximately 50 essential words which would then be represented using picture symbols on a communication board intended to enable people with $\mathrm{CCN}$ to report a crime or abuse. Any communication board with picture symbols is limited as to the number of symbols. The decision to limit this particular board to 50 symbols was driven by both design factors and the consideration that larger numbers of symbols on one display can be confusing to users or difficult to access due to motor limitations. In addition to the symbols, an alphabet and illustration of a human body would be provided as shown in communication aids developed by Bryen and Ravitch (go to http://disabilities.temple.edu/aacvocabulary/e4all.shtml\#index, scroll down to "Emergency Communication 4 ALL Communication Aid" and click on either English, Spanish, or Haitian Creole to view these PDF boards which served as the template).

A workshop was held on the topic of crime and abuse as a first step in explaining the problem and identifying the needed vocabulary for telling somebody if you had been the victim of crime, abuse or neglect (Bryen, 2009). Following the workshop, all participants were asked whether they would be interested in participating in a research project and to join a focus group. All 26 participants consented. The workshop with focus groups was selected as the method of data collection that yielded information from multiple sources containing rich contextual data, allowing the researchers to capture the experiences, individual perspectives and opinions of participants who were already interested in this sensitive topic (Brotherson \& Goldstein, 1992; Krogh \& Lindsay, 1999; Krueger, 1988; Morse, 1996). Participants were asked to participate in the particular focus group in their first language, or in a language in which they felt comfortable, and this resulted in two large focus groups, namely Afrikaans (n $=11)$ and English $(n=11)$ and one small focus group, namely isiZulu $(n=4)$. No Sepedi- 
Reducing crime risk through communication

speaking participants were present. Due to the fact that Sepedi is an indigenous African language which is spoken widely in Southern Africa with an estimated four million speakers, including speakers in Zimbabwe and Namibia (UNESCO World Languages Report Survey Questionnaire, 2008), it was decided to hold a separate Sepedi focus group. Ten teachers from a special school participated in this focus group. Except for the isiZulu focus group, the size of the other groups was in the region suggested as being optimal ( $6-15$ participants) (Frey $\&$ Fontana, 1993). The Sepedi focus group was facilitated by a teacher who works in the field of AAC, while the other 3 were facilitated by speech language pathologists. All facilitators had a primary interest in disability and AAC.

\section{Participants}

A total of 36 participants were included in the four focus groups. Four of the participants were people with disability themselves. Their occupations varied and included teachers (14), speech-language pathologists (11), occupational therapists (5) and one each of the following professions: a psychologist, a counsellor, a criminologist, a criminal lawyer, a disability activist as well as a personal assistant. Their qualifications ranged from only having Grade $12(n=2)$, to a diploma $(n=3)$, bachelors degree $(n=16)$, and post-graduate qualification $(n=15)$. All participants were adults, with six between ages 20 and 30, 18 between 31 and 40, and 12 between 41 and 50 years old. Regarding experience, it is clear that all of the participants had experience in this field, except for two who stated that they had less than a year's experience. The remaining participants mostly had more than 6 years of experience $(n=22)$, with 5 and 6 respectively having 4-5 years and 1-3 years experience, respectively. There was an equal number of participants who spoke Afrikaans and English as a first language $(\mathrm{n}=11$ each), ten who spoke Sepedi $(\mathrm{n}=10)$ and a small number who spoke isiZulu as a primary language $(n=4)$. 
Reducing crime risk through communication

\section{Procedures}

To determine the vocabulary a person with $\mathrm{CCN}$ would need to tell about abuse, crime or neglect responding from their own experience in the field, one open-ended question was used (Krueger, 1988), namely: "Which words do you think a person with CCN would need if he/she wanted to tell that he/she had been the victim of crime, abuse or neglect?" Participants were reminded not to include any words that refer to specific body parts, as it was decided that a picture of a human would be provided on the back of the communication board along with an alphabet, as per Bryen and Ravitch (2009). As a result of the commonalties participants shared and the fact that they mostly knew each other from the workshop, rapport was quickly established. Therefore, the focus group was experienced as non-threatening.

The facilitators led the respective focus groups in a semi-structured discussion of the question (Frey \& Fontana, 1993) and asked for clarification during the discussion when some concepts were unclear or in cases where the data was open to misinterpretation (Krefting, 1991). Facilitators also encouraged the participants to participate actively, to share their wealth of experiences, to understand that no suggested vocabulary items would be regarded as "stupid" or "silly," and reassured them that their responses would remain anonymous. Flexibility was allowed in terms of the sequence of suggested words (e.g., all did not have to think of verbs or nouns) enabling facilitators to listen to the discussion, observe and respond to what they saw and heard. Structural coherence was thus maintained, increasing credibility (Krefting, 1991). In an attempt to enhance trustworthiness, member checks were included, which entailed that the facilitators read out all of the words at the end of the discussion, asking participants whether they agreed, disagreed, or if any important words were overlooked (Hoffart, 1991).

After brainstorming and listing all the possible words that could be useful and relevant, participants were asked to prioritize their top 55 words from the complete list. The 
Reducing crime risk through communication

facilitators spent some time debriefing directly after the focus groups to discuss their interpretations in order to enhance trustworthiness (Peshkin, 1993). No areas that needed additional probing or clarification were noted. Debriefing is an important part of investigator triangulation and was included to heighten the credibility of the data obtained (Brotherson \& Goldstein, 1992; Kimchi, Polivka \& Stevenson, 1991).

Data analysis

An EXCEL spreadsheet was developed, containing all 220 words that were generated by the four focus groups. Words were then ranked from 4 (words that were present on all 4 lists) to 1 (words that were only recorded on 1 list). All words that appeared on 2 lists or more were considered for inclusion on the final board. This was followed by a discrepancy analysis where the words were compared to Mayer-Johnson's Picture Communication Symbols $\left(\mathrm{PCS}^{\mathrm{TM}}\right)$ to determine if symbols existed for all of these words in order to develop a communication board.

\section{Results}

Both the English and Sepedi focus group generated 53 words, with the Afrikaans focus group providing 55 words, and the isiZulu focus group generated 59 words. These words are shown in Table 1. When comparing words on the four language lists, a small overlap was noticed. Only 5 words (hit, man, sad, sore, woman) were present in all four languages. A total of 28 and 24 words were present in two or three of the languages, respectively. In the list that represents words from three languages, the miscellaneous category was the largest with eight words (how, what, when, where, who, do not, please, stop), seven nouns including four words related to people (I, doctor, family, police, clothes, home, toilet) five verbs (burn, forced, help, tell, touch) and four descriptors (angry, in, out, scared).

Similarly, the words that appeared on at least 2 language lists represented a variety of 
Reducing crime risk through communication

categories. The noun categories contained 14 words each (alcohol, car, day, food, gun, money, mother, night, secret, school, sex, sweets, they, work) with the verb group being only slightly smaller with 8 words (bleed, get, know, look, shout, steal, swear, threaten). Five descriptors were included (ashamed, alone, bad, friendly, under) as well as one miscellaneous word/phrase (not on this board).

Of the words that were discarded because they only appeared in only one language, the majority came from the isiZulu focus group (21 words), followed by the Sepedi group (20), English (14) and Afrikaans group (13). These discarded words are shown in Table 2.

A survey conducted via a national South African electronic mailing list for persons interested in AAC indicated that Mayer-Johnson's Picture Communication Symbols ${ }^{\mathrm{TM}}$ (PCS $\left.{ }^{\mathrm{TM}}\right)$ is used widely in South Africa, especially amongst the school-aged population of persons with little of no functional speech $(\mathrm{CCN})$. It was thus decided to represent the vocabulary selected by means of PCS ${ }^{\mathrm{TM}}$.

The discrepancy analysis revealed that these 56 words were represented by a staggering 219 symbols, of which 2 words (swear, threaten) did not have any existing PCS ${ }^{\mathrm{TM}}$ symbols. Following this research these two symbols were developed. The word that had the most possible symbols, was "I" (16). The majority of words were indicated by between 1 and 6 symbols each (see Table 3 ). The high number of symbols for the different concepts is understandable, given the fact that $\mathrm{PCS}^{\mathrm{TM}}$ is perceived to be a highly iconic symbol set. In these types of symbol sets, developers often try and enhance the iconicity of the symbols by adding more background features (Bornman, Alant, du Preez, 2009). This is done in an attempt to allow users to select the symbol that they can best identify with - hence the provision of 16 different symbols for "I", allowing the person who needs to use the symbol, to select the most appropriate one. In a multi-cultural context, such as South Africa, this is a Sisyphean task! Hence it was decided to select the most generic symbol throughout that would 
Reducing crime risk through communication

not typically depict gender or race.

In the design of the boards, attempts were made to optimize the number of messages that could be communicated and to ensure that the symbols were of adequate size. Therefore a double-sided display was used with one side containing the 56 PCS $^{\text {TM }}$ symbols and the illustration of male and female human bodies, and the other side containing an alphabet-board so that literate users would be able to spell novel words. (Illiterate users would most likely only be able to use the PCS ${ }^{\mathrm{TM}}$ symbols). The same illustration of the human bodies was also included at the back of the boards (one for adults and one for children), so that the individual could point to important body parts if needed.

The vocabulary on the board was arranged using a combination of the modified Fitzgerald key (Musselwhite \& St. Louis, 1988) which groups symbols from left to right in the following categories: miscellaneous words (e.g., social words, wh-words, exclamations, and pro-nouns), verbs, descriptors, and nouns, and the principles of Aided Language Stimulation board design (Goossens', Crain, \& Elder, 1994). The grammatical categories were also usually colour coded to facilitate visual and cognitive processing (Goossens', et al., 1994). Appendix A shows one of the final communication boards constructed. Each of the boards in the appendix is in both English and Sepedi. Hereafter the board was translated into 2 additional South African languages, namely Afrikaans and isiZulu. In order to accommodate the multi-lingual South African context, all of the boards display at least two different language options, with one gloss at the top and the other below the symbol. Go to http://www. caac.up.ac.za or go to http://disabilities.temple.edu/aacvocabulary/e4all.shtml\#index, scroll down to "Emergency Communication 4 ALL Communication Aid" and click on either South African English, Afrikaans, Sepedi, or isiZulu to download these PDF boards for children or for adults). 


\section{Discussion}

The value of this research study is that it provides some evidence-based vocabulary for individuals with complex communication needs that might assist them in telling somebody if they have been a victim of crime, abuse or neglect. As stated earlier by Bryen (2008), AAC systems have traditionally not included vocabulary related to crime or abuse. For literate AAC users who are able to construct their own messages by using an alphabet-based board, this might not be problematic. However, in 2003, South Africa's literacy rate was reported to be 86.4 (Central Intelligence Agency, 2009), which is lower than expected. This is, indeed, problematic. Not only are very few individuals with disabilities literate (because the special school curriculum did not focus on "academic tasks" such as literacy for these children (INDS 1997), communication partners may also be illiterate. This is particularly true in the rural areas where the incidence of disability (and consequently abuse) is the highest. In these cases, individuals would have to be able to communicate using a pre-constructed communication board containing the relevant concepts and pictographic symbols.

Secondly, in a multi-lingual country, such as South Africa, many interactions would involve at least two languages. Often the speaker and the communication partner do not share the same language. In order to assist with this process, all of the boards contained two languages, i.e., English and either Afrikaans, isiZulu, or Sepedi. The individual who relies on AAC will thus point to the pictographic symbol, and the partner will be able to read the gloss in their preferred language. However, for clarity sake, the partner can then read the gloss aloud for the person who uses AAC's first language - thereby indicating that the message had been understood.

Thirdly, it is hoped that the process of developing the communication boards described in this article might also be useful to the AAC community in other countries, and that developers and manufacturers of speech-generating AAC devices and different symbol sets 
Reducing crime risk through communication

and systems will include concepts related to abuse as described. Parents and therapists should also ensure that these concepts are taught during appropriate sexuality training programmes so that individuals become familiar with these concepts.

There are, however, limitations to this research that should be noted. The method for identifying the relevant vocabulary was based on reflection of the participants (a metalinguistic task) rather than from recorded conversations. This strategy was selected due to the sensitive nature of the topic. In order to increase the validity of this process, however, four different focus groups were held and data was compared in order to compile the most representative list.

The limitations related to the purpose of the communication board should also be noted. It was developed with the sole purpose of telling someone about abuse so that it might be stopped or the individual being helped rather than reporting the crime or abuse in court. There was concern that using this communication aid might not stand in court once it was used to disclose the alleged rape or abuse. As such, after disclosure using the board might jeopardize the credibility of its use to testify or give evidence in court. However, though recent research by Bryen (2010) suggests that this has not been the case in the United States, we decided to be cautious in its use in South Africa. The purpose of these communication boards is simply to act as a first line of disclosure so that a person who relies on AAC can tell a trusted person if she/he had been a victim of crime, abuse or neglect.

\section{Conclusion}

Addressing issues related to abuse requires a multi-disciplinary approach, involving a variety of stakeholders and strategies. This project has been a first attempt in giving a voice to one of the most vulnerable groups in South Africa, namely individuals with complex communication needs. Any interaction with a person who relies on a communication board 
Reducing crime risk through communication

requires a certain amount of training and familiarity with the process, if it is to be used optimally. A generic topic-based board such as this also stands the risk of being too broad and non-specific, and hence customization of individual boards may also be needed. Therefore, these communication boards should be seen as a first attempt in addressing this issue that has not been addressed in the past. All governments are under obligation to protect its citizens, including those with a disability, from all forms of sexual exploitation and any form of abuse. Hence, the South African Government has put many laws in place, the most recent being the ratification of the United Nations Convention of the Rights of Persons with Disabilities in 2008, as well as earlier international conventions and national legislation (e.g., Constitution of South Africa, the National Disability Strategy, the Children's Act and the Sexual Offences Act). However, the traditional approaches to "protecting" people with disability, for example, through institutionalization, might have inadvertently kept them from accessing the tools and resources needed to protect themselves (Powers \& Oschwald, 2004).

Therefore, ending the silence of crimes against children and adults does not only require legalistic approaches, but rather a multi-disciplinary approach, using several strategies focusing on (1) the individual with a disability, (2) the family, (3) disability service providers, (4) law enforcement, (5) the criminal justice system, and (6) public policy. Ending the silence of crimes against individuals with disabilities also means helping them understand what to do if they have been a victim of a crime; providing training which includes self-defence and personal safety; teaching them the difference between healthy sexuality and sexual abuse; establishing partnerships between the justice system, advocates and service providers; developing communication access for people with developmental disabilities who don't communicate in traditional ways (sign language or communication boards); supporting parents to address their fears; working aggressively with the justice system to support investigation, prosecution and the provision of victim assistance services; expanding existing 
Reducing crime risk through communication

legislation to include people with disabilities; and aggressively applying civil rights laws and to create national and international public awareness through personal stories.

It is our hope that this research and the resultant communication boards will provide one means of risk reduction. If a person with $\mathrm{CCN}$ can tell and be heard, this is likely to reduce the risk of being a victim of rape, sexual or physical abuse, or neglect. It has the potential of ending the silence of victims of crime.

\section{References}

BBC. (2009). Big jump in S Africa sex offences. BBC News. Retrieved February 1, 2010, from http://newsbbc.co.uk/2/hi/8269159.stm

Bornman, J., Alant, E., \& Du Preez, A. (2009). Translucency and Learnability of Blissymbols in Different Countries: An Exploration. Augmentative and Alternative Communication, 25, 287-298.

Borthwick, C., \& Crossley, R. (1998). Gagged in the box-non-speech communication and the law. Paper presented at the Eighth Biennial ISAAC Conference, Dublin: ISAAC.

Brotherson, M. J., \& Goldstein, B.L. (1992). Quality design of focus groups in early childhood special education research. Journal of Early Intervention, 16, 334-342.

Brownridge, D.A. (2006). Partner violence against women with disabilities: prevalence, risk and explanations. Violence against Women, 12, 805-822.

Bryen, D. N. (2010). Review of court cases in the United States related to testifying in court as a witness of a crime or abuse on their own behalf using an AAC system. Unpublished paper, Philadelphia: Temple University.

Bryen, D. N. (2008). Vocabulary to support socially-valued adult roles. Journal of Augmentative and Alternative Communication, 24, 294-30. 
Reducing crime risk through communication

Bryen, D. N. (2009). Speaking Up and Speaking Out: Reducing the Risk of being a victim of crime and of natural/man-made disasters. Paper presented at the Centre for Augmentative and Alternative Communication, University of Pretoria, Pretoria, South Africa, August 25-26.

Bryen, D. N., \& Frantz, B. (2000). Reducing the victimization of people with significant speech disabilities. Paper presented at the Ninth Biennial ISAAC Conference, Philadelphia: ISAAC.

Bryen, D.N., \& Ravitch, R. (2009). Emergency communication 4 all: Picture communication aid.

Philadelphia: Institute on Disabilities at Temple University.

Bryen, D. N., Carey, A., \& Frantz, B. (2005). Ending the Silence: Adults who use augmentative communication and their experiences as victims of crime. Journal of Augmentative and Alternative Communication, 19, 123-134.

Central Intelligence Agency. (2009). World Factbook. Retrieved 1 April, 2009, from https://www.cia.gov/library/publications/the-world-factbook/index.html.

Coetzee, C. (2005). An explorative study of the training needs for Investigating Officers interviewing young Victims of Sexual abuse. Unpublished Masters Thesis, Stellenbosch University, Stellenbosch, South Africa.

Cohen, L., \& George, Z. (2007, 4 November). The evil our children live with. The Times. Retrieved February 1, 2010, from http://www.timeslive.co.za/sundaytimes/article88008.ece

Davies, L. (2002). People with mental disabilities and sexual violence: The ARC. Retrieved September 4, 2009, from http://www.theorac.org.

Frey, J. H., \& Fontana, A. (1993). The group interview in social research. In D.L. Morgan (Ed.), Successful focus groups. Advancing the state of the art (pp. 20-34). Newbury, 
Reducing crime risk through communication

England: Sage Publications.

Goossens', C. A., Crain, S., \& Elder, P. S. (1994). Communication displays for engineered preschool environments. Solana Beach, CA: Mayer-Johnson.

Grobbelaar-du Plessis, I. (2007). African women with disabilities: the victims of multilayered discrimination. Suid Afrika Publiekreg / South Africa Public Law, 22, 406-421.

Groce, N. E., \& Trasi, R. (2004). Rape of individuals with disability: AIDS and the folk belief of Virgin Cleansing. The Lancet, 363(9422), 1663-1664.

Hanass-Hancock, J. (2009). Interweaving conceptualizations of gender and disability in the context of vulnerability to HIV/AIDS in KwaZulu Natal, South Africa. Sexuality and Disability, 27, 35-47.

Hoffart, N. (1991). A member check procedure to enhance rigor in naturalistic research. Western Journal of Research Practice, 13(4), 522-534.

Howe, K. (2000). Violence against women with disabilities: An overview of the literature. Retrieved February 4, 2010, from http://www.wwda.org.au/keran.htm Integrated National Disability Strategy. (1997). Office of the Deputy President. Retrieved April 1, 2010, from http://www.info.gov.za/whitepapers/1997/disability.htm

Jewkes, R. K., Sikweyiya, Y., Morrell, R., \& Dunkle, K. (2008). Understanding men's health and use of violence: interface of rape and HIV/AIDS in South Africa. Technical report. Pretoria. Medical Research Council.

Keilty, J., \& Connelly, G. (2001). Making a statement: An exploratory study of barriers facing women with intellectual disability when making a statement about sexual assault. Disability and Society, 16, $274-289$.

Kimchi, J., Polivka, B., \& Stevenson, J. S. (1991). Triangulation: Operational definitions. Nursing Research, 40, 364-366.

Krefting, L. (1991). Rigor in qualitative research: The assessment of trustworthiness. The 
Reducing crime risk through communication

American Journal of Occupational Therapy, 45, 214-222.

Krogh, K.S., \& Lindsay, P.H. (1999). Including people with disabilities in research: Implications for the field of augmentative and alternative communication. Augmentative and Alternative Communication, 15, 222-233.

Krueger, R.A. (1988). Focus groups: A practical guide for applied research. Newbury, England: Sage Publications.

Lehohla, P. (2003). Census 2001: Census in Brief. Report number 03-02-03(2001). Pretoria: Statistics South Africa.

Madu, S. N. (2001). The prevalence and patterns of childhood abuse and perpetrator relationship among a sample of university students. South African Journal of Psychology, 31(4), 32-37.

Martin, S. L., Ray, N., Sotres-Alvares, D., Kupper, L .L., Moracco, K. E., \& Dickens, P.A. (2006). Physical and sexual assault of women with disabilities. Violence against women, 12, 83-837.

Mayer-Johnson, R. (1992). The picture communication symbols. Solana Beach, CA: MayerJohnson Co.

McCall Smith, A. (2000). Tears of the Giraffe. New York: Anchor Books.

Morse, J. M. (1996). What is a method? Qualitative Health Research, 6, 467-468.

Musselwhite, C. R., \& St. Louis, K. W. (1988). Communication programming for persons with severe handicaps: Vocal and augmentative strategies (2nd ed.). Austin, TX: PRO-ED.

Nation Master (2009). Statistics. Retrieved 1 April 2010, from http://www.nationmaster.com/statistics

Nosek, M. A., Howland, C.A., \& Young, M. E. (1997). Abuse of women with disabilities: Policy implications. Journal of Disability Policy Studies, 8, 157-175. 
Reducing crime risk through communication

Phasha, N., \& Myaka, L. (2009). A custom distorted: Beliefs about sexual abuse involving teenagers with intellectual disability at a rural setting in South Africa. Unpublished paper. University of Johannesburg.

Peshkin, A. (1993). The goodness of qualitative research. Educational Researcher, 22, 23-29.

Pierce, L., \& Bozalek, V. (2004) Child abuse in South Africa: an examination of how child abuse and neglect are defined. Child Abuse and Neglect, 28, 817-832.

Powers, L.E., \& Oschwald, M. (2004). Violence and Abuse against people with disabilities: experiences, barriers and prevention strategies. Portland, OR: Oregon Health and Science University Center on Self-Determination. Retrieved April 18, 2010, from http://www.directcareclearinghouse.org/download/AbuseandViolenceBrief\%203-704.pdf

Rand, M. R., \& Harrell, E. (2009). Crime against people with disabilities, 2007. National Crime Victimization Survey. NCJ 227814, October 2009.

Rousso, H. (2003). Education for all: A Gender and Disability perspective. Retrieved February 2, 2010, from http://siteresources.worldbank.org/DISABILITY/Resources/2806581172610312075/EducationforallRousso.pdf

Sobsey, D. (1994). Violence and abuse in the lives of people with disabilities. The end of silent acceptance? Baltimore: Paul H. Brooks.

Sobsey, D., \& Doe, T. (1991). Patterns of sexual abuse and assault. Sexuality and Disability, 9, 243-259.

Statistics South Africa (2001). Prevalence of Disabilities in South Africa. National Census 2001 Report, pp. 11.

Statistics South Africa. (2009). Mid-Year population estimates 2009. Retrieved April 1, 2010, from http://www.statssa.gov.za/publications/P0302/P03022009.pdf 
Reducing crime risk through communication

Sullivan, P. M. (2000). Violence and abuse against children with disabilities. Unpublished paper. Center for Abused Children with Disabilities. Boys town National Research Hospital.

UNESCO. (n.d). World Languages Report Survey Questionnaire (2008). Retrieved April 2, 2008, from http://www.salanguages.com/unesco/northernsotho.htm

UNICEF. (2005). Violence again disabled children. New York: United Nations, 2 - 31. UNITED NATIONS. (1999). Convention on the rights of the child: Initial reports of States parties due in 1997: South Africa. 05/22/1999. CRC/C/51/Add.2. (State Party Report). Retrieved April 5, 2010, from http://www.unhchr.ch/tbs/doc.nsf/0/d2c94c67c4df8870802567ef0035d7c8?Opendocu ment

Williams, C. (1993. Vulnerable victims? A current awareness on the victimization of people with learning disabilities. Disability, Handicap and Society, 8(2), 161-172. 
Reducing crime risk through communication

Table 1

Vocabulary generated by four focus groups

\begin{tabular}{|c|c|c|c|c|c|c|c|}
\hline \multirow[t]{2}{*}{ Syntactical Categories } & \multicolumn{2}{|c|}{$\begin{array}{c}\text { Words that appear in all } \\
4 \text { languages }\end{array}$} & \multicolumn{2}{|c|}{$\begin{array}{c}\text { Words that appear in } 3 \\
\text { languages }\end{array}$} & \multicolumn{2}{|c|}{$\begin{array}{c}\text { Words that appear in } 2 \\
\text { languages }\end{array}$} & \multirow[t]{2}{*}{ Totals } \\
\hline & Words & Language & Words & Language & Words & Language & \\
\hline \multirow[t]{8}{*}{ Miscellaneous } & & & Don't & EAZ & They & $\mathrm{ZS}$ & \\
\hline & & & How & ASZ & $\begin{array}{l}\text { Not on this } \\
\text { board }\end{array}$ & EA & \\
\hline & & & Please & EZS & & & \\
\hline & & & Stop & EAZ & & & \\
\hline & & & What & ASZ & & & \\
\hline & & & When & ASZ & & & \\
\hline & & & Where & ASZ & & & \\
\hline & & & Who & ASZ & & & \\
\hline Category Total & 0 & & 8 & & 2 & & 10 \\
\hline \multirow[t]{10}{*}{ Verbs } & Hit & EASZ & Burn & EAZ & Bleed & ES & \\
\hline & & & Forced & EZS & Feel & EZ & \\
\hline & & & Help & EZA & Get & ES & \\
\hline & & & Tell & EAZ & Know & EA & \\
\hline & & & Touch & EAZ & Look & EA & \\
\hline & & & & & Removed & $\mathrm{ZS}$ & \\
\hline & & & & & Shout & $\mathrm{AZ}$ & \\
\hline & & & & & Steal & EA & \\
\hline & & & & & Swear & $\mathrm{SZ}$ & \\
\hline & & & & & Threaten & $\mathrm{EZ}$ & \\
\hline Category Total & 1 & & 5 & & 10 & & 16 \\
\hline \multirow[t]{5}{*}{ Descriptors } & Hurt & EASZ & Angry & EAZ & Alone & EA & \\
\hline & $\mathrm{Sad}$ & EASZ & Inside & EAS & Ashamed & EA & \\
\hline & & & Outside & EAS & $\mathrm{Bad}$ & EA & \\
\hline & & & Scared & EZA & Friendly & $\mathrm{AZ}$ & \\
\hline & & & & & Under & AS & \\
\hline Category Total & 2 & & 4 & & 4 & & 10 \\
\hline
\end{tabular}

$\mathrm{E}=$ English, $\mathrm{A}=$ Afrikaans, $\mathrm{S}=$ Sepedi, $\mathrm{Z}=$ isiZulu 
Reducing crime risk through communication

\begin{tabular}{|c|c|c|c|c|c|c|c|}
\hline \multirow[t]{2}{*}{ Syntactical Categories } & \multicolumn{2}{|c|}{$\begin{array}{c}\text { Words that appear in all } \\
\text { four languages }\end{array}$} & \multicolumn{2}{|c|}{$\begin{array}{c}\text { Words that appear in three } \\
\text { languages }\end{array}$} & \multicolumn{2}{|c|}{$\begin{array}{c}\text { Words that appear in two } \\
\text { languages }\end{array}$} & \multirow[t]{2}{*}{ Totals } \\
\hline & Words & Language & Words & Language & Words & Language & \\
\hline \multirow[t]{11}{*}{ Nouns } & Man & EASZ & Clothes & ESZ & Alcohol & EA & \\
\hline & Woman & EASZ & Doctor & ESZ & Car & AS & \\
\hline & & & Family & ESA & Day & EA & \\
\hline & & & Home & EAS & Food & $\mathrm{ZA}$ & \\
\hline & & & Inside & ESZ & Gun & $\mathrm{SZ}$ & \\
\hline & & & Police & ESZ & Money & EA & \\
\hline & & & Toilet & EAZ & Mother & SZ & \\
\hline & & & & & Night & EA & \\
\hline & & & & & Secret & $\mathrm{EZ}$ & \\
\hline & & & & & School & EA & \\
\hline & & & & & Sex & ES & \\
\hline Category Total & 2 & & 7 & & 11 & & 20 \\
\hline TOTAL WORDS & 5 & & 24 & & 28 & & 58 \\
\hline
\end{tabular}

$\mathrm{E}=$ English, $\mathrm{A}=\mathrm{A}$ frikaans, $\mathrm{S}=$ Sepedi, $\mathrm{Z}=$ isiZulu 
Reducing crime risk through communication

Table 2

Discarded words per language

\begin{tabular}{|c|c|c|c|}
\hline IsiZulu & Sepedi & English & Afrikaans \\
\hline Attacked & Ambulance & Dead/death & Animals \\
\hline Aunt & At the back & Dirty & Bother \\
\hline Body & Brother & Here & Child \\
\hline Both & Escape & Important & Close \\
\hline Breast & Father & Kiss & Hard \\
\hline Clean & Hospital & Lives with me & Listen \\
\hline Court & Hurry & More & Many/much \\
\hline Cried & In front & Pay/bribe & My fault \\
\hline Didn't listen & Knife & Question & Must \\
\hline Give & My kids & Safe & Nappy change \\
\hline Grandma & My name is & Street & Other places \\
\hline Ignore & Nurse & TV / Movie & $\mathrm{Up}$ \\
\hline Individual & On top & Want & Wheelchair / device \\
\hline Lawyer & Pull & Weapon & \\
\hline Neighbour & Put & & \\
\hline Penis & Sister & & \\
\hline Stabbed & Telephone & & \\
\hline Tied & To dress & & \\
\hline Uncle & Undress & & \\
\hline Vagina & Water & & \\
\hline Why? & & & \\
\hline
\end{tabular}


Reducing crime risk through communication

Table 3

Symbols used in South Africa according to electronic mail survey

\begin{tabular}{|c|c|c|c|c|}
\hline & Reply from & Symbols used & Purpose & No. of individuals \\
\hline \multirow{5}{*}{ 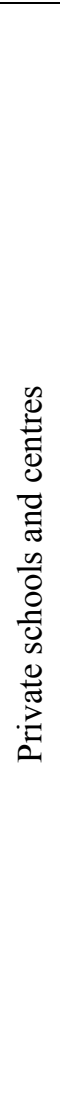 } & Pathways Kloof & $\begin{array}{c}\text { PCS }^{\mathrm{TM}} \\
\text { Symbolstix } \\
\text { SA sign languge }\end{array}$ & $\begin{array}{l}\text { Primary symbol system } \\
\text { Secondary symbols } \\
\text { Support for spoken } \\
\text { English }\end{array}$ & \\
\hline & $\begin{array}{l}\text { Pathways Polokwane } \\
\text { enrichment centre }\end{array}$ & $\begin{array}{c}\text { PCS }^{\mathrm{TM}} \\
\text { Writing with symbols } \\
\text { Basic sign }\end{array}$ & $\begin{array}{l}\text { Communication, visual } \\
\text { timetables, pre-literacy, } \\
\text { literacy, routines, } \\
\text { schedules }\end{array}$ & $\begin{array}{l}\text { All children } \\
\text { Younger class }\end{array}$ \\
\hline & Opkyk Pathways Brits & $\mathrm{PCS}^{\mathrm{TM}}$ & $\begin{array}{c}\text { PECS, schedules } \\
\text { Equi therapy } \\
\text { Used with younger } \\
\text { children and babies }\end{array}$ & $\begin{array}{l}11 \\
20\end{array}$ \\
\hline & Whizz Kids & $\mathrm{PCS}^{\mathrm{TM}}$ & & 20 \\
\hline & $\begin{array}{c}\text { Little leaps nursery } \\
\text { school for children with } \\
\text { autism }\end{array}$ & $\begin{array}{c}\text { PCS }^{\mathrm{TM}} \\
\text { Writing with symbols } \\
\text { (Widgit/Rebus) }\end{array}$ & PECS & 16 \\
\hline \multirow{3}{*}{ 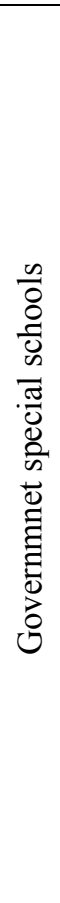 } & Pretoria CP School & $\begin{array}{c}\text { PCS }^{\mathrm{TM}} \\
\text { PCS }^{\mathrm{TM}} \text { and alphabet } \\
\text { Widgit (Writing with } \\
\text { symbols) }\end{array}$ & $\begin{array}{c}\text { Preschool: Learning } \\
\text { language, help with routine } \\
\text { Basic needs } \\
\text { communication (children } \\
\text { aged 10-15) } \\
\text { Basic needs, expression } \\
\text { (children aged 13-17) } \\
\text { Making readers for } \\
\text { children }\end{array}$ & $\begin{array}{l}50 \\
7 \\
4\end{array}$ \\
\hline & Browns School & $\mathrm{PCS}^{\mathrm{TM}}$ & & \\
\hline & New Hope School & $\mathrm{PCS}^{\mathrm{TM}}$ and alphabet & $\begin{array}{c}\text { In nursery: (1)ALS } \\
\text { (2) communication } \\
\text { purposes (expressive) } \\
\text { School-going: Expressive }\end{array}$ & $\begin{array}{l}20 \\
\text { Few } \\
\text { Few }\end{array}$ \\
\hline
\end{tabular}




\begin{tabular}{|c|c|c|c|c|}
\hline & & & $\begin{array}{l}\text { (communication boards, } \\
\text { devices) } \\
\text { Work Orientation: (1) } \\
\text { ALS, classroom activities } \\
\text { (2) Expressive }\end{array}$ & Few \\
\hline \multirow{9}{*}{$\begin{array}{l}\frac{n}{0} \\
\frac{0}{0} \\
0 \\
\dot{0} \\
\dot{0} \\
0\end{array}$} & Pro Nobis School & $\mathrm{PCS}^{\mathrm{TM}}$ & & \\
\hline & YWCA special school & $\mathrm{PCS}^{\mathrm{TM}}$ & & \\
\hline & Sunrise School & $\begin{array}{c}\text { PCS } \\
\text { PCS }^{\mathrm{TM}} \text { abjects, photos } \\
\end{array}$ & $\begin{array}{l}\text { Schedules and ALS for } \\
\text { Junior } 1 \text { and } 2 \text {, } \\
\text { Learner with CCN- } \\
\quad \text { expression }\end{array}$ & $\begin{array}{c}30 \\
1 \\
1\end{array}$ \\
\hline & Vista Nova School & $\begin{array}{c}\text { Clicker with CPL } \\
\text { (Clicker picture library) } \\
\text { PCS }^{\text {TM }} \text { (Boardmaker) }\end{array}$ & $\begin{array}{l}\text { Individual users } \\
\text { (expression?) } \\
\text { Visual schedules, social } \\
\text { stories, visually enhanced } \\
\text { teaching and therapy } \\
\text { equipment }\end{array}$ & $\begin{array}{c}4 \\
\text { Many }\end{array}$ \\
\hline & St Raphael's School & $\mathrm{PCS}^{\mathrm{TM}}$ & & \\
\hline & RP Moodley School & $\mathrm{PCS}^{\mathrm{TM}}$ & $\begin{array}{l}\text { Schedules, booklets, } \\
\text { labels, instructions }\end{array}$ & $\begin{array}{c}\text { All junior phase } \\
\text { learners } \\
\text { Learners with CCN } \\
5 \text { learners on autistic } \\
\text { spectrum }\end{array}$ \\
\hline & $\begin{array}{c}\text { Stepping stones SNC } \\
\text { School }\end{array}$ & $\mathrm{PCS}^{\mathrm{TM}}$ & & \\
\hline & $\begin{array}{l}\text { School for children with } \\
\text { autism (name?) }\end{array}$ & $\mathrm{PCS}^{\mathrm{TM}}$ & PECS, schedules & 15 \\
\hline & Bel Porto School & $\begin{array}{c}\text { Makaton } \\
\text { PCS }^{\mathrm{TM}} \\
\text { Clicker symbol library }\end{array}$ & & $\begin{array}{c}3 \\
18 \\
4\end{array}$ \\
\hline
\end{tabular}


Reducing crime risk through communication

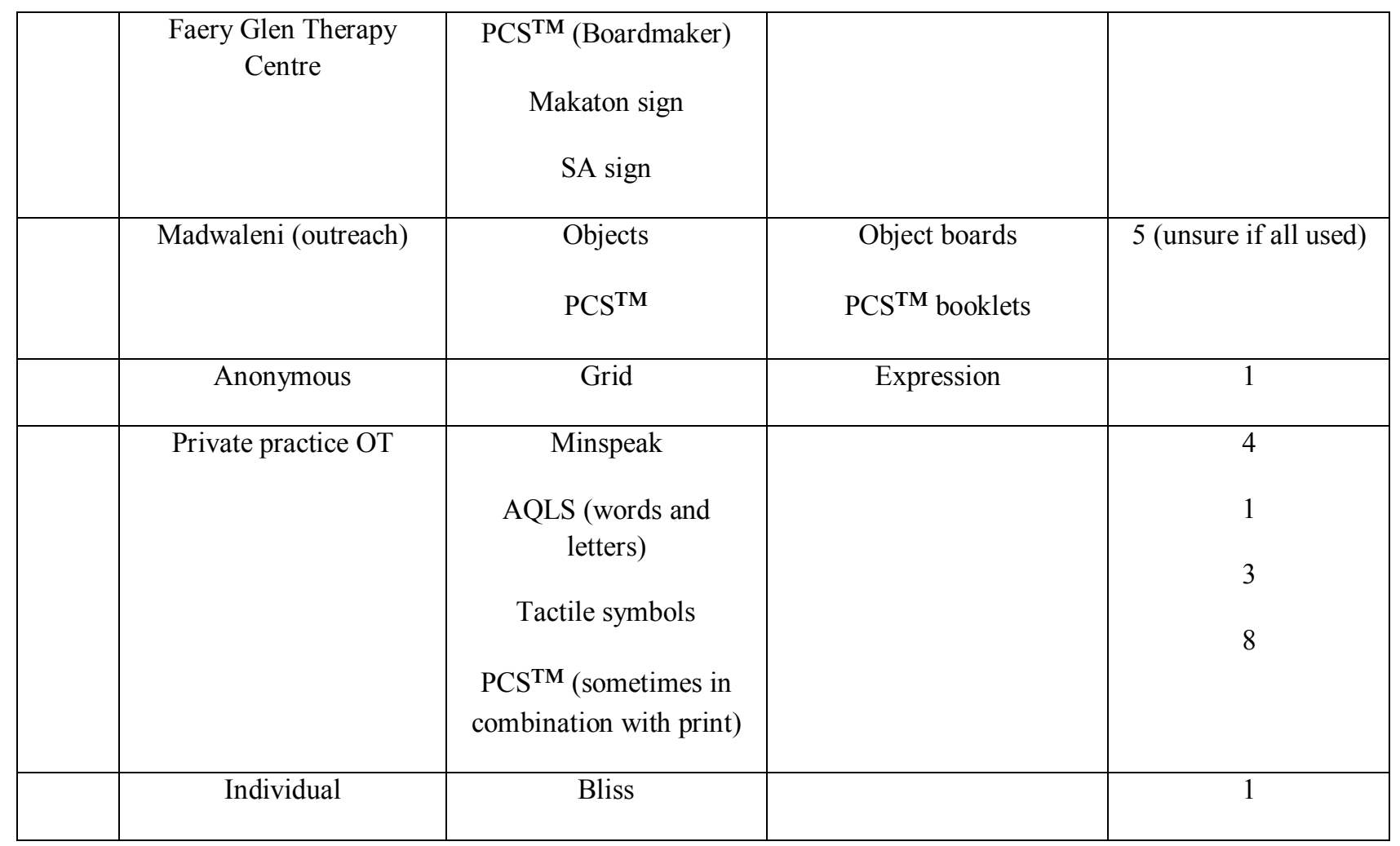


Reducing crime risk through communication

Table 4

Discrepancy analysis: Words and possible Picture Communication Symbols (PCS ${ }^{\mathrm{TM}}$ )

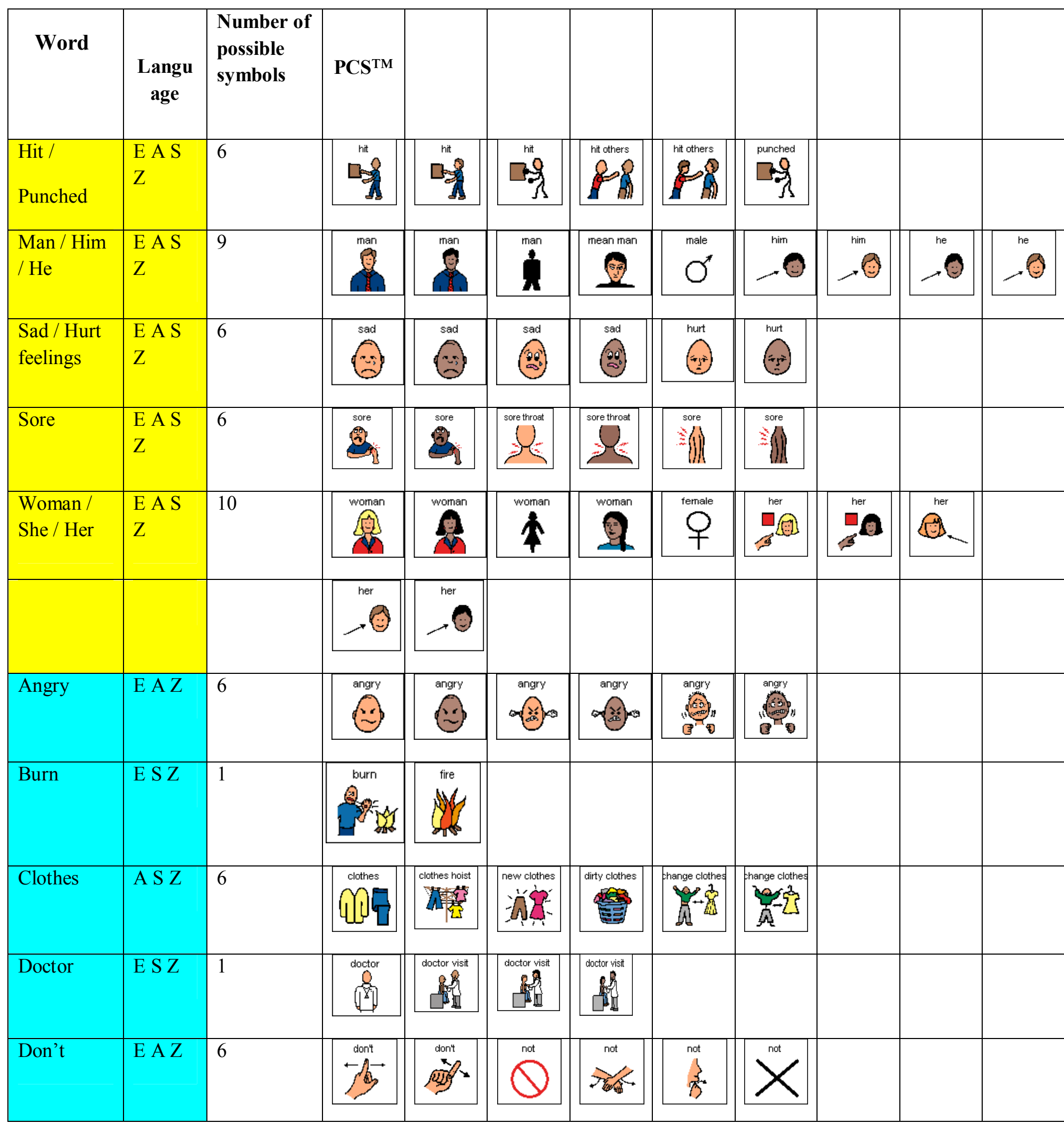




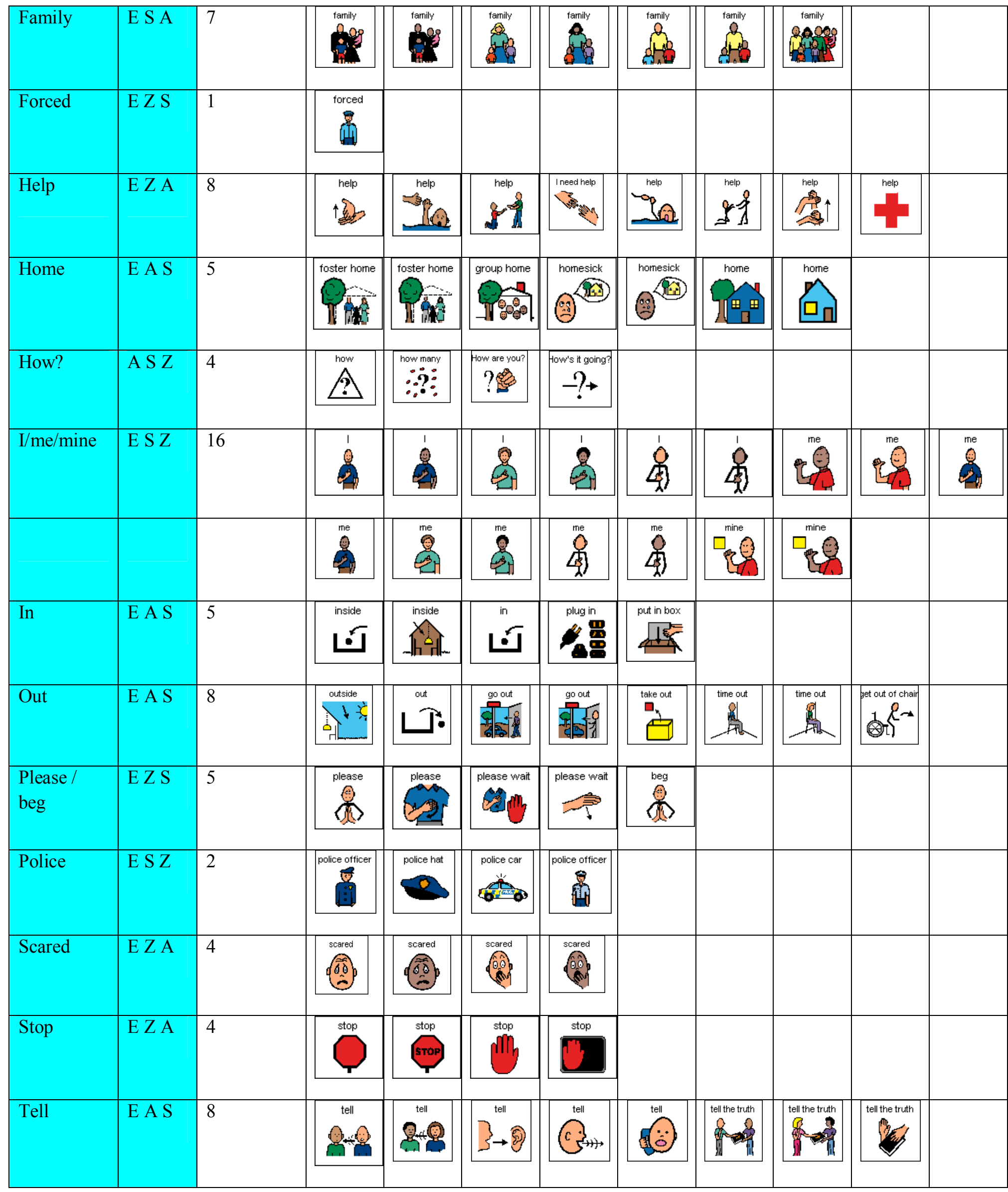




\begin{tabular}{|c|c|c|c|c|c|c|c|c|c|c|}
\hline $\begin{array}{l}\text { Toilet / } \\
\text { bathroom }\end{array}$ & E A Z & 4 & 18 & \begin{tabular}{|l|} 
toilet \\
$\equiv$ \\
$\square$
\end{tabular} & get toilet paper & 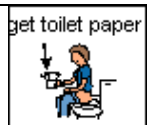 & 8 & 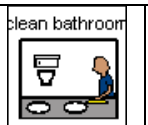 & 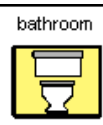 & take a bath \\
\hline Touch & $\mathrm{E} \mathrm{A} \mathrm{Z}$ & 6 & & touch & take & 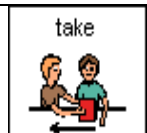 & $\begin{array}{l}\text { take } \\
8 \% \\
84\end{array}$ & touch gently & & \\
\hline What? & A S Z & 2 & what & what & & & & & & \\
\hline When? & A S Z & 1 & & & & & & & & \\
\hline Where? & A S Z & 1 & where & & & & & & & \\
\hline Who? & A S Z & 1 & & & & & & & & \\
\hline Alcohol & E A & 1 & & & & & & & & \\
\hline Alone & E A & 2 & alone & & & & & & & \\
\hline $\begin{array}{l}\text { Ashamed / } \\
\text { shy }\end{array}$ & E A & 1 & & & & & & & & \\
\hline $\mathrm{Bad}$ & E A & 3 & bad & bad & bad & & & & & \\
\hline Bleed & E S & 2 & blood & blood & & & & & & \\
\hline Car & A S & 3 & car & car & maxi-taxi & & & & & \\
\hline Day & E A & 2 & & early & & & & & & \\
\hline Food & $\overline{Z A}$ & 4 & & hot food & $\begin{array}{l}\text { food } \\
\text { 90 }\end{array}$ & हि & & & & \\
\hline
\end{tabular}




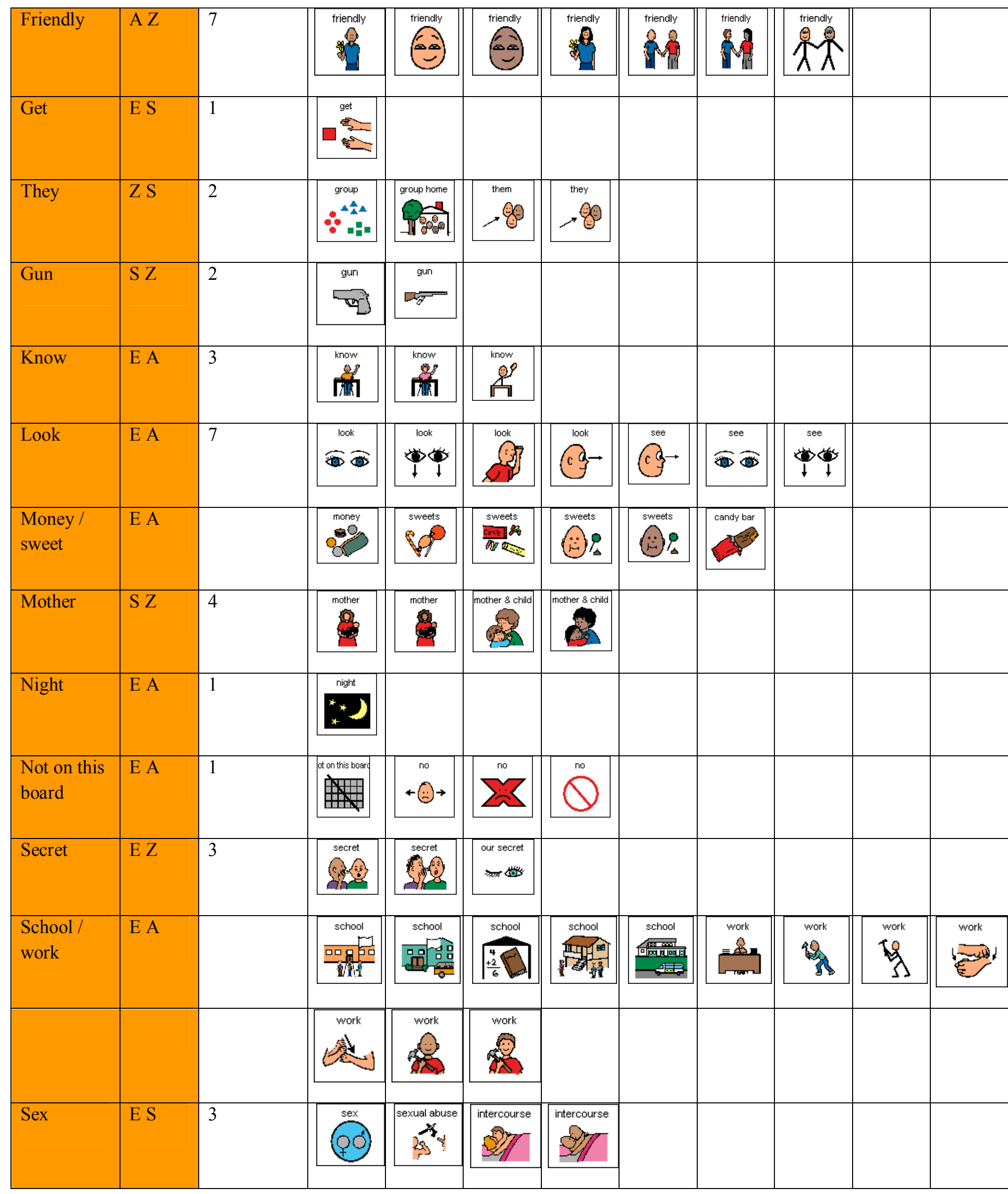


Reducing crime risk through communication

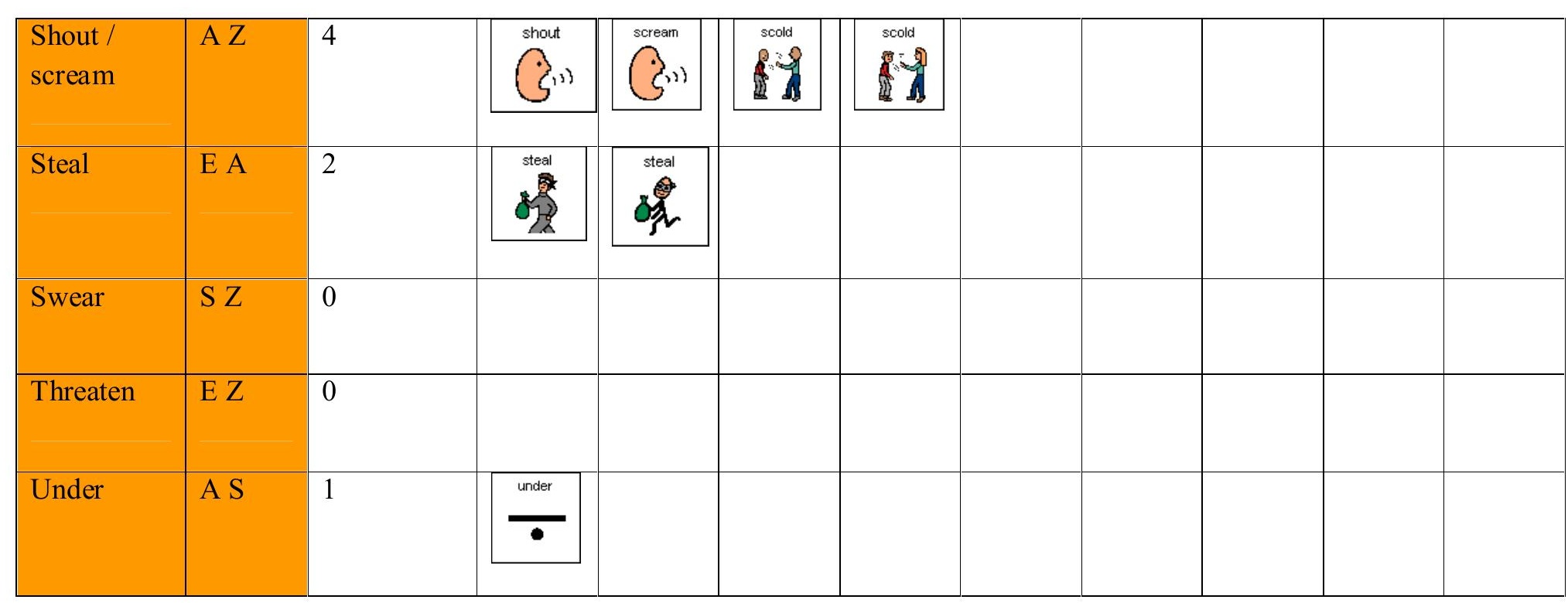




\section{Appendix A}

Communication for ALL: You Can Tell and be Heard (Sepedi and English)

Communication for ALL: You can tell and be heard / Poledisano ya BOHLE: O ka bolela o ka ba wa theeletšwa

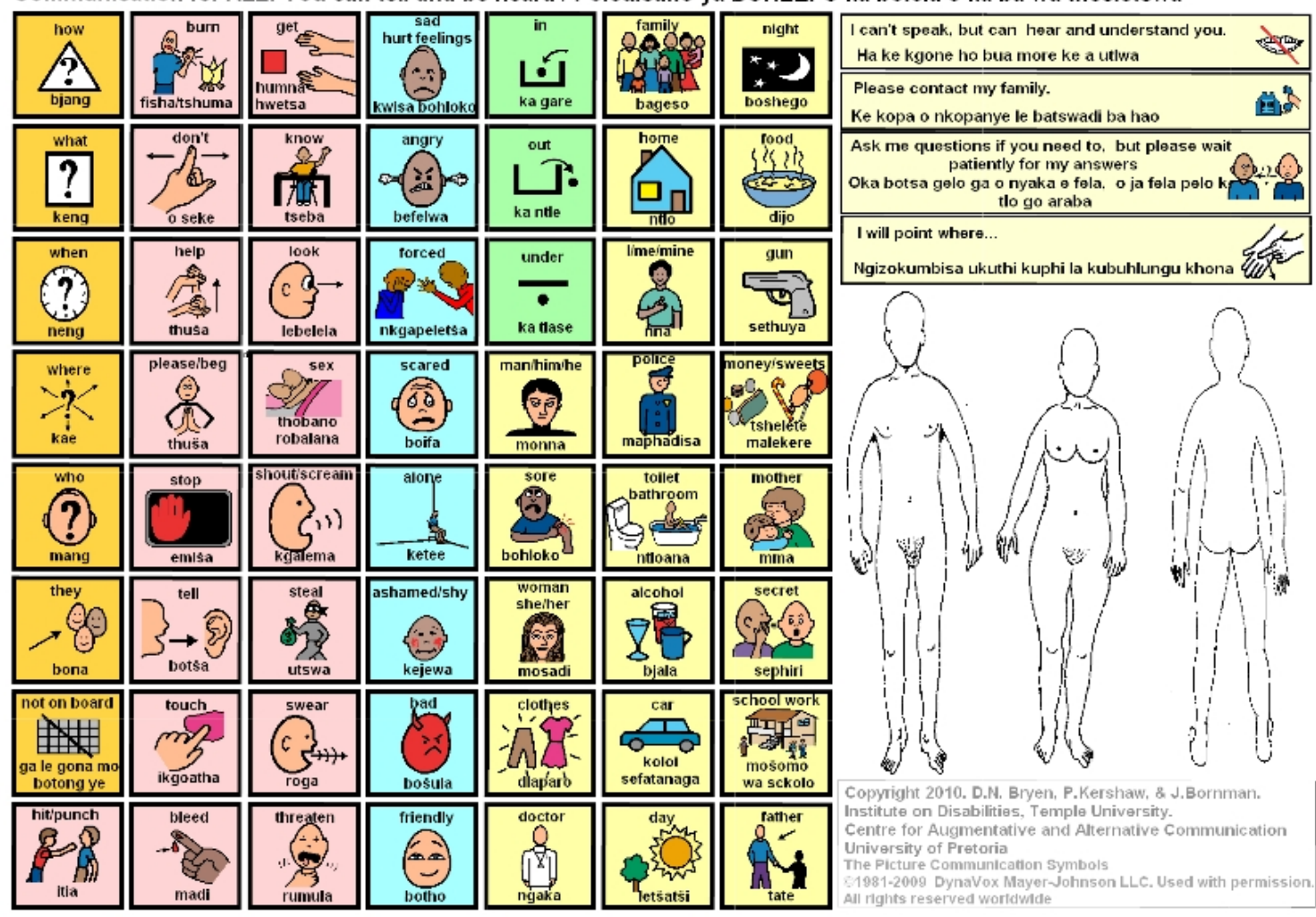

Communication for ALL: You can tell and be heard / Poledisano ya BOHLE: O ka bolela o ka ba wa theeletšwa

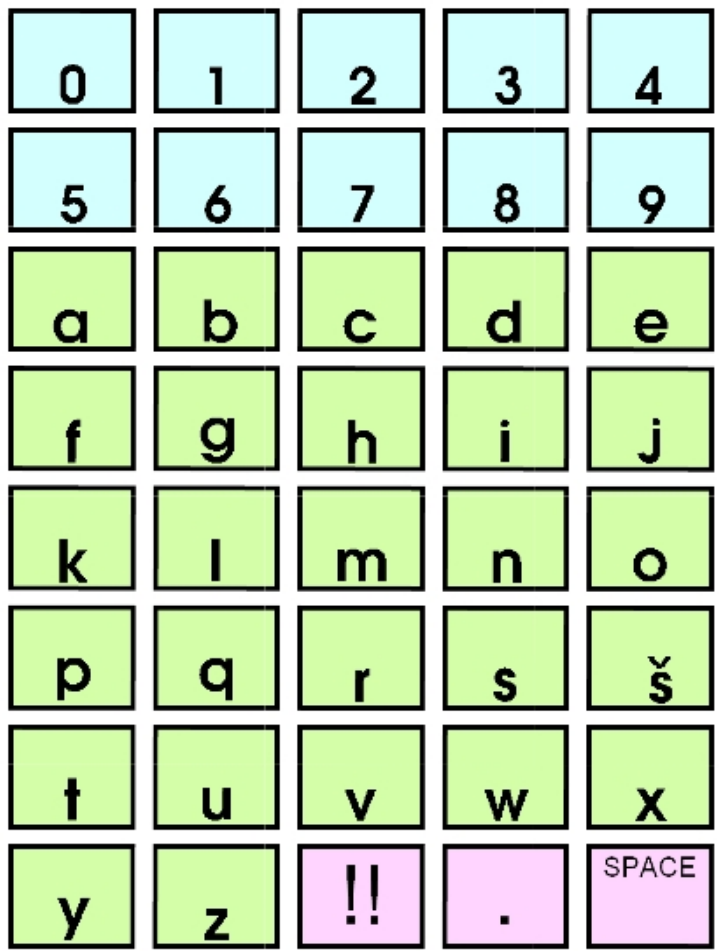

\begin{tabular}{l}
\hline $\begin{array}{l}\text { I can't speak, but can hear and understand you. } \\
\text { Ha ke kgone ho bua more ke a utiva }\end{array}$ \\
\hline \hline $\begin{array}{l}\text { Please contact my family. } \\
\text { Ke kopa o nkopanye fe batswadi ba hao }\end{array}$ \\
\hline \hline $\begin{array}{l}\text { Ask me questions if you need to, but please wait } \\
\text { patiently for my answers } \\
\text { Oka botsa geio ga o nyaka a feia, o ja feia pelo ke } \\
\text { to go araba }\end{array}$ \\
\hline $\begin{array}{l}\text { I will point where... } \\
\text { Ngizokumbisa ukuthi kuphi ja kubuhingu khona }\end{array}$
\end{tabular}
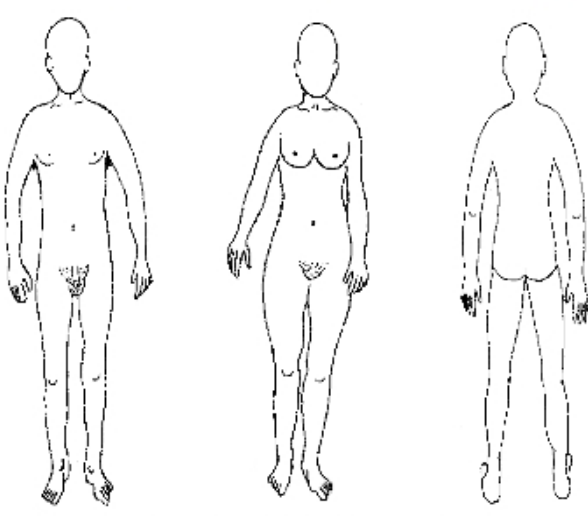